\title{
POSTAWY MŁODZIEŻY WOBEC ALTERNATYWNYCH FORM ŻYCIA MAŁŻEŃSKO-RODZINNEGO. NA PODSTAWIE BADAŃ SOCJOLOGICZNYCH W KATOLICKICH LICEACH OGÓLNOKSZTAŁCĄCYCH W SZCZECINIE
}

\author{
WPROWADZENIE
}

Alternatywne formy życia małżeńsko-rodzinnego trwale wpisują się w krajobraz społeczny ponowoczesności. Poszerzający się zakres społecznej akceptacji dla kształtowania się nowych form życia rodzinnego, obserwuje się także w społeczeństwie zorientowanym tradycjonalistycznie, jakim nadal wydaje się być społeczeństwo polskie. Związek małżeński w świadomości Polaków jest wciąż istotnym fundamentem życia rodzinnego oraz najbardziej pożądaną wartością zarówno dla dorosłych Polaków, jak i młodszych pokoleń. Nie oznacza to jednak, że alternatywne formy życia małżeńsko - rodzinnego nie znajdują się w obszarze zainteresowań młodzieży jako rozwiązanie czasowe, pośrednio prowadzące do założenia trwałej i tradycyjnej rodziny.

\section{ALTERNATYWNE FORMY ŻYCIA MAŁŻEŃSKIEGO I RODZINNEGO JAKO ZJAWISKO SPOŁECZNE}

Wśród nowych form życia rodzinnego uwagę badaczy skupia zjawisko kohabitacji. Kohabitację zwykle definiuje się jako związek partnerów żyjących bez zawartego formalnie małżeństwa. Samo zjawisko kohabitacji obejmuje jednak szerszy zakres pojęciowy, ponieważ może odnosić się także do par, które żyją ze sobą bez ślubu jednak w swoim mniemaniu uważają siebie za parę małżeńską. Ponadto za-

* Ks. Dominik SzcZYGIELSKI - doktorant w Instytucie Socjologii Katolicki Uniwersytet Lubelski Jana Pawła II, e-mail: dominikszczygielski@o2.pl. 
mieszkiwanie razem na sposób małżeński bez formalnego aktu zawarcia związku małżeńskiego może być traktowane przez partnerów jako etap przygotowujący do ślubu, przybierający formę przedłużającego się okresu narzeczeństwa lub jako świadoma decyzja rezygnacji ze ślubu ${ }^{1}$.

W literaturze przedmiotu można napotkać rozgraniczenie pojęć kohabitacja i konkubinat. W tej klasyfikacji kohabitacja oznacza związek, któremu towarzyszy współzamieszkiwanie partnerów, bez zawarcia formalnego związku, natomiast konkubinat odnosi się do stabilnego związku partnerów bez wspólnego zamieszkania ${ }^{2}$. Obecnie wyróżnia się typ stary i typ nowy kohabitacji. Stary typ tworzą związki składające się przynajmniej z jednej osoby owdowiałej, bądź po separacji, lub rozwodzie. Z kolei typ nowy tworzą pary, które nigdy nie zawarły związku małżeńskiego ${ }^{3}$.

W Polsce w roku 2011 liczba osób deklarujących się jako partnerzy żyjący w związku kohabitacyjnym wyniosła prawie 650 tys. (wzrost o $62 \%$ z niewiele ponad 396 tys. w roku 2002), jednak udział tej kategorii w całej populacji jest nadal niewielki - w 2011 roku pary kohabitanckie stanowiły niespełna 2,0\% ogółu ludności w wieku 15 lat i więcej. Zdecydowana większość partnerów mieszka W mieście ( $80 \%$ ogółu par kohabitujących), ma wykształcenie średnie/ policealne (34\%), najczęściej są to osoby w wieku 25-34 lat (37\%), kawalerowie/panny (61\%) lub osoby rozwiedzione $(28 \%)^{4}$.

Wśród najczęstszych przyczyn upowszechniania się kohabitacji wskazuje się na spadek zaufania do trwałości małżeństwa spowodowany wzrostem liczby rozwodów, niekorzystną sytuację ekonomiczną, trudności z rozpoczęciem dorosłego życia czy brak presji społecznej ${ }^{5}$. Do innych przyczyn zalicza się także osłabienie poziomu religijności i oddziaływania instytucji promujących wzorce bardziej tradycyjne pod względem obyczajowości i zachowań seksualnych ${ }^{6}$.

Kolejną, alternatywną wobec tradycyjnie rozumianego małżeństwa są związki jednopłciowe. Prawo osób homoseksualnych do zawarcia legalnego związku małżeńskiego i adopcji jest obecnie kwestią, która najbardziej polaryzuje opinię publiczną. Dostosowanie ustawodawstwa uwzględniającego ten typ związków i charakter uprawnień znamionuje zwykle aprobatę społeczną dla tej formy życia małżeńskiego. W literaturze specjalistycznej homoseksualistę definiuje się jako

${ }^{1}$ M. Sikorska, Nowa matka, nowy ojciec, nowe dziecko. O nowym układzie sit $w$ polskich rodzinach, Warszawa 2009, s. 135-136.

2 D. Gębuś, Rodzina tak, ale jaka?, Warszawa 2006, s. 71.

${ }^{3}$ D. Ruszkiewicz, Życie w pojedynkę - ucieczka od rodziny czy znak naszych czasów?, Łódź 2008, s. 87.

${ }^{4}$ Główny Urząd Statystyczny, Ludność. Stan i struktura demograficzno-społeczna. Narodowy Spis Powszechny Ludności i Mieszkań 2011, Warszawa 2013, s. 68-70 i 237-245. http://www.stat. gov.pl/cps/rde/xbcr/gus/LUD_ludnosc_stan_str_dem_spo_NSP2011.pdf dostęp on-line 03.11.2013

${ }_{5}^{5}$ D. Gizicka, Kohabitacja jako alternatywna forma życia matzeńskiego, „Roczniki Nauk Społecznych" 2008, t. 36, z. 1, s. 199.

${ }^{6}$ P. Szukalski, Kohabitacja w Polsce, w: Rodzina w zmieniajacym się społeczeństwie polskim, red. W. Warzywoda-Kruszyńska, P. Szukalski, Łódź 2004, s. 52-53. 
osobę, „której pociąg płciowy jest wyłącznie lub prawie wyłącznie skierowany do osób własnej płci i która wyłącznie lub prawie wyłącznie w ten sposób uzyskuje

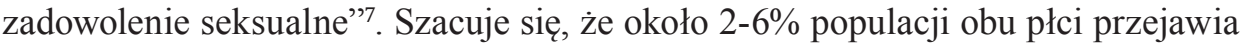
skłonności wyłącznie homoseksualne, a różne natężenie zainteresowań kontaktami homoseksualnymi ujawnia blisko $1 / 3$ mężczyzn i $1 / 4$ kobiet $^{8}$.

Pomimo iż socjologowie obserwują wśród ludzi młodych nasilający się trend akceptacji i tolerancji dla zjawiska homoseksualizmu ${ }^{9}$, to w skali makro Polacy nastawieni są raczej nieprzychylnie do pomysłu zalegalizowania homoseksualnych związków partnerskich. Z badań przeprowadzonych przez CBOS w lutym 2013 roku na reprezentatywnej grupie Polaków wynika, że aż 3/5 ankietowanych (60\% wskazań na odpowiedzi „zdecydowanie nie” i „raczej nie”) negatywnie ustosunkowuje się do pomysłu umożliwiającego zawieranie związków partnerskich przez osoby tej samej płci. Co trzeci respondent wyraża pogląd przeciwny (33\% łącznie dla odpowiedzi ,zdecydowanie tak” i „raczej tak”), a niemal co piętnasty badany (7\%) ma problem z zajęciem jednoznacznego stanowiska w tej kwestii ${ }^{10}$.

Ostatnim omawianym zagadnieniem jest tzw. samotność z wyboru. Osoby wybierające taką formę życia dorosłego powszechnie nazywa się singlami bądź singielkami, a sam styl życia singla wpisuje się jednoznacznie w kontekst społeczeństwa ponowoczesnego, w którym często zindywidualizowane i świadome wybory młodego pokolenia podyktowane są motywami obejmującymi sferę życia prywatnego i zawodowego. Single to osoby, które najogólniej rzecz ujmując świadomie wybierają bezżeństwo i rezygnują z budowania trwałych relacji emocjonalnych, pomimo osiągnięcia dojrzałości psychicznej i fizycznej oraz niezależności ekonomicznej. Aktualnie bycie singlem nie wiąże się z ostracyzmem otoczenia i nie skutkuje marginalizacją czy wykluczeniem, co więcej jest to pewien styl życia utożsamiany z nowoczesnym sposobem definiowania przez jednostkę swojej tożsamości, w której dużą rolę odgrywa zindywidualizowana hierarchii wartości oraz wartość samorealizacji ${ }^{11}$.

W literaturze naukowej można napotkać na różne próby zdefiniowania osoby żyjącej samotnie - singla. Jak referuje Aldona Żurek, „najbardziej klasyczna definicja singla głosi, że jest to kobieta lub mężczyzna, którzy nie pozostają w związku małżeńskim ani też w nieformalnym związku hetero- lub homoseksualnym (...) Są nimi zatem ci, o których w polskim społeczeństwie mówi się, że są niezamężne (nieżonaci) lub stanu wolnego"12. Inne napotykane w piśmiennictwie

7 Z. Lew-Starowicz, M. Lew-Starowicz, Homoseksualizm, Warszawa 1999, s. 9.

8 Tamże, s. 11.

${ }^{9}$ T. Biernat, P. Sobierajski, Młodzież wobec matżeństwa i rodziny. Raport z badań, Toruń 2007, s. 22-21.

${ }^{10}$ M. Feliksiak, Stosunek do praw gejów i lesbijek oraz zwiąków partnerskich, Komunikat z badań CBOS, BS/24/2013, Warszawa 2013, s. 6.

${ }_{11}$ T. Biernat, P. Sobierajski, Młodzież wobec matżeństwa i rodziny. Raport z badań, Toruń 2007, s. $18-22$.

${ }^{12}$ A. Żurek, Single. Żyjąc w pojedynkę, Poznań 2008, s. 19. 
naukowym definicje opisują singla jako każdą osobę niemieszkającą w domu z rodzicami lub partnerem, lub jako osobę żyjącą samotnie, tworzącą jednoosobowe gospodarstwo domowe. W celu uszczegółowienia pojęcia singla można uwzględnić w analizach poszczególne subkategorie osób wyróżnianych w jej obrębie, a mogą to być osoby stanu wolnego (kawalerowie/panny), osoby owdowiałe lub rozwiedzione ${ }^{13}$. W nowszej perspektywie zjawisko to dotyczy zwłaszcza osób młodych, profesjonalistów w sferze życia zawodowego, mieszkających w dużych ośrodkach miejskich, zorientowanych na sukces materialny i prestiż, którym życie w pojedynkę umożliwia wydłużenie edukacji i zdobywanie kompetencji zawodowych ${ }^{14}$.

Pomimo iż zjawisko samotności z wyboru nie jest niczym nowym w przestrzeni społecznej (kategorie: „stary kawaler/stara panna”), to relatywnie nowe są powody i przyczyny decydowania się na taki styl życia. Obecnie wśród katalizatorów generujących to zjawisko wymienia się: chęć osiągnięcia wysokiego statusu materialnego, skupianie się na samorealizacji i karierze zawodowej, nieodczuwanie potrzeby wiązania się z kimś na stałe, wysokie kryteria wymagań wobec przyszłego partnera/ partnerki bądź problem ze znalezieniem odpowiedniego kandydata/ kandydatki. Wizerunek medialny singla/ singielki jest pozytywny i zwykle dotyczy osoby wykształconej, nowoczesnej, dobrze sytuowanej i niezależnej ${ }^{15}$.

Z perspektywy ponowoczesnych przemian zrozumiałe stają się wybory i wymierne korzyści płynące z samotnego trybu życia. Wśród zalet życia singla wymienia się $\mathrm{m}$. in. niezależność, brak zobowiązań, swobodę w dysponowaniu czasem wolnym, zasobność materialną. W społecznej percepcji nie brakuje także i wad związanych z życiem w pojedynkę: poczucie osamotnienia, brak wsparcia i bliskości drugiej osoby, presja otoczenia ${ }^{16}$. Dlatego też, zdaniem Aldony Żurek, świat relacji społecznych singli cechuje wysoki stopień nasycenia więzi, kontaktów, społecznych relacji, opartych na aktywności zawodowej, lokalno-sąsiedzkiej czy towarzyskiej, które pozwalają uniknąć obawy przed izolacją i samotnością ${ }^{17}$.

Na podstawie danych GUS z roku 2011 szacuje się, że liczba gospodarstw domowych w Polsce wyniosła 13 milionów 572 tysiące (wzrost o ok. 235 tyś. w porównaniu z rokiem 2002), z czego $24 \%$ stanowiły gospodarstwa jednoosobowe (spadek o 0,8 pkt. procentowego w porównaniu z rokiem 2002). Jednoosobowe gospodarstwa

13 Tamże, s. 20-38.

14 Tamże, s. 43.

15 M. Szyszka, Współczesna rodzina-polskie dylematy, w: Społeczeństwo-Przestrzeń-Rodzina. Księa jubileuszowa dedykowana Profesorowi Piotrowi Kryczce, red. M. Szyszka, Lublin 2009, s.284-285.

16 Tamże.

17 A. Żurek, Czas wolny singli-pomiędzy rodziną a przyjaciółmi, w: Miłość, wierność i uczciwość na rozstajach współczesności. Kształty rodziny współczesnej, red. W. Muszyński, E. Sikora, Toruń 2008, s. 431. 
domowe tworzą stosunkowo często osoby starsze, zwłaszcza kobiety i wcale nie oznacza to, że są to gospodarstwa domowe singli. Jak zauważają specjaliści GUS, relatywnie duży odsetek gospodarstw jednoosobowych powiązany jest głównie z sytuacją ekonomiczną rodzin oraz preferencjami ludzi młodych, którzy odkładają decyzje matrymonialne i prorodzinne na później ${ }^{18}$. Zjawisko życia w pojedynkę nie osiąga w Polsce jeszcze niepokojących rozmiarów. O wiele wyższe odsetki jednoosobowych gospodarstw domowych notuje się w krajach skandynawskich: Dania - 44\%, Szwecja - 43\%, Finlandia $-38 \%{ }^{19}$.

W kontekście upowszechniania się nowych form życia rodzinnego warto zapytać młodsze pokolenia Polaków o społeczną ocenę tego zjawiska. Młodzież licealna stanowi kategorię społeczną szczególnie podatną na zmiany o charakterze społeczno-kulturowym, które nierzadko stoją w sprzeczności z uznawanymi dotąd normami życia społecznego. $Z$ tego względu zasadne wydaje się pytanie o to, czy młodzież, na ogół prezentująca liberalne podejście do norm życia społecznego, w podobny sposób będzie odnosić się do przemian w zakresie uznawanych form życia małżeńskiego i rodzinnego. Głównym celem niniejszego opracowania jest więc poznanie opinii i stosunku młodzieży szkół średnich wobec zjawiska kohabitacji, życia w pojedynkę i możliwości zawierania związków przez pary jednopłciowe. Badania, na których opiera się niniejsze opracowanie przeprowadzono w kwietniu 2013 roku w dwóch liceach katolickich w Szczecinie: Katolickim Liceum Ogólnokształcącym oraz Liceum Ogólnokształcącym Towarzystwa Salezjańskiego, na łącznej próbie 293 uczniów wszystkich poziomów i profili. Badanie przeprowadzono metodą kwestionariuszową z wykorzystaniem techniki ankiety audytoryjnej. W kwestionariuszu ankiety wykorzystano także pytania zawarte w kwestionariuszach $\mathrm{CBOS}^{20}$.

\section{KOHABITACJA, ŻYCIE W POJEDYNKĘ I ZWIĄZKI HOMOSEKSUALNE}

Z opublikowanych w 2008 roku badań socjologicznych Doroty Gizickiej, przeprowadzonych wśród lubelskiej młodzieży wynika, iż kohabitacja nie stanowi, zdaniem uczniów lubelskich liceów realnego zagrożenia dla instytucji małżeństwa. Niespełna

${ }^{18}$ Główny Urząd Statystyczny, Gospodarstwa domowe w 2011 roku - wyniki spisu ludności i mieszkań 2011 - material na konferencje prasowa $w$ dniu 29.01.2013 r., Warszawa 2013, s. 2-3. http://www.stat.gov.pl/cps/rde/xbcr/gus/LU_Gospodarstwa_domowe_w_2011r_wyniki_NSP2011. pdf dostęp on-line 10.11.2013.

19 T. Szlendak, Socjologia rodziny. Ewolucja, historia, zróżnicowanie, Warszawa 2012, s. 468.

${ }^{20} \mathrm{R}$. Boguszewski, Kontrowersje wokó różnych zjawisk dotyczacych życia matżeńskiego i rodzinnego, Komunikat z badań CBOS, BS/54/2008, Warszawa 2008; N. Hipsz, Społeczne oceny alternatyw życia matzeńskiego, Komunikat z badań CBOS, BS/32/2013, Warszawa 2013. 
3/5 ankietowanych (58,3\% łącznie dla odpowiedzi „raczej nie” i „zdecydowanie nie") stwierdziło, że kohabitacja nie zastąpi w przyszłości małżeństwa. Są to jednak poglądy o charakterze raczej umiarkowanym, gdyż 36,6\% badanych wyraziło mniej stanowczą dezaprobatę (,raczej nie"). Odmiennego zdania był niemal co czwarty lubelski licealista $(25,2 \%$ łącznie dla kategorii odpowiedzi „raczej tak” i „zdecydowanie tak”). W tej grupie badanych zdecydowaną aprobatę dla ewentualnego zastąpienia małżeństwa przez kohabitację wyraziło 6,8\% respondentów. Umiarkowany sceptycyzm lubelskich licealistów wobec zjawiska kohabitacji wydaje się zaskakiwać, jeśli weźmie się pod uwagę fakt, iż prawie połowa z nich, planując swój stan cywilny w przyszłości deklaruje chęć wcześniejszego zamieszkania z partnerem na próbę $(49,8 \%)^{21}$.

Sytuacja kształtuje się podobnie w przypadku młodzieży szkół katolickich ze Szczecina i okolic. Niewiele ponad połowa badanych uczniów zjawisko konkubinatu ocenia mniej lub bardziej negatywnie (53\% łącznie dla kategorii odpowiedzi „raczej negatywnie" i ,zdecydowanie negatywnie”). Dezaprobata ankietowanych ze Szczecina, podobnie jak w przypadku lubelskiej młodzieży, przybiera stonowaną formę, gdyż prawie $1 / 3$ badanych wyraża się o kohabitacji raczej nieprzychylnie (34,2\% odpowiedzi „raczej negatywnie”). Grono osób pochlebnie wypowiadających się o zjawisku konkubinatu stanowi niemalże $1 / 4$ respondentów $(24,7 \%$ łącznie dla kategorii „raczej pozytywnie” oraz „zdecydowanie pozytywnie”). Warto zwrócić uwagę na relatywnie wysoki odsetek osób $(22,3 \%)$, które nie potrafią jednoznacznie ocenić zjawiska niesformalizowanych związków.

Oceny zjawiska konkubinatu, które formułują uczniowie szkół katolickich ze Szczecina, są znacząco różnicowane przez ich stosunek do wiary. Odsetek uczniów nieprzychylnie ustosunkowanych wobec konkubinatu jest wyższy wśród uczniów bardziej religijnych niż niereligijnych, w przeciwieństwie do uczniów obojętnych religijnie i niewierzących, wśród których niemal połowa ocenia to zjawiska ogólnie jako pozytywne $(65,7 \%$ łącznie dla kategorii odpowiedzi „raczej negatywne” i „zdecydowanie negatywne” wśród uczniów głęboko wierzących i wierzących wobec 50,6\% łącznie dla kategorii „,raczej pozytywnie” i „zdecydowanie pozytywnie" wśród uczniów obojętnych i niewierzących).

${ }^{21}$ D. Gizicka, Kohabitacja - droga do matżeństwa czy jego alternatywa?, w: Miłość, wierność i uczciwość na rozstajach wspótczesności. Kształty rodziny współczesnej, red. W. Muszyński, E. Sikora, Toruń 2008, s. 424-425. 
Tabela 1. Ocena zjawiska konkubinatu i życia w pojedynkę według stosunku do wiary (\%).

\begin{tabular}{|c|c|c|c|c|}
\hline & \multicolumn{2}{|c|}{ Stosunek do wiary } & \multirow[b]{2}{*}{ Ogółem } \\
\hline & & $\begin{array}{l}\text { Głęboko } \\
\text { wierzący } \\
\text { i wierzący }\end{array}$ & $\begin{array}{c}\text { Obojętni } \\
\text { i niewierzący }\end{array}$ & \\
\hline & & $\mathrm{N}=207$ & $\mathrm{~N}=85$ & $\mathrm{~N}=292$ \\
\hline \multirow{6}{*}{$\begin{array}{c}\text { Ocena zjawiska } \\
\text { konkubinatu }^{\text {a) }}\end{array}$} & Zdecydowanie pozytywnie & 2,9 & 20,0 & 7,9 \\
\hline & Raczej pozytywnie & 11,1 & 30,6 & 16,8 \\
\hline & Raczej negatywnie & 39,1 & 22,4 & 34,2 \\
\hline & Zdecydowanie negatywnie & 26,6 & 0,0 & 18,8 \\
\hline & Trudno powiedzieć & 20,3 & 27,1 & 22,3 \\
\hline & Ogółem & 100,0 & 100,0 & 100,0 \\
\hline \multirow{6}{*}{$\begin{array}{c}\text { Ocena zjawiska } \\
\text { życia w pojedynkę }\end{array}$} & Zdecydowanie pozytywnie & 2,9 & 10,6 & 5,1 \\
\hline & Raczej pozytywnie & 8,2 & 28,2 & 14,0 \\
\hline & Raczej negatywnie & 38,6 & 25,9 & 34,9 \\
\hline & Zdecydowanie negatywnie & 15,0 & 4,7 & 12,0 \\
\hline & Trudno powiedzieć & 35,3 & 30,6 & 33,9 \\
\hline & Ogółem & 100,0 & 100,0 & 100,0 \\
\hline \multirow{6}{*}{$\begin{array}{l}\text { Czy osoby żyjące } \\
\text { w pojedynkę tzw. } \\
\text { single mają ciekaw- } \\
\text { sze życie niż osoby } \\
\text { żyjące w stałych } \\
\text { związkach?c) }\end{array}$} & Zdecydowanie tak & 2,4 & 9,4 & 4,5 \\
\hline & Raczej tak & 10,7 & 14,1 & 11,7 \\
\hline & Raczej nie & 36,4 & 35,3 & 36,1 \\
\hline & Zdecydowanie nie & 26,2 & 7,1 & 20,6 \\
\hline & Trudno powiedzieć & 24,3 & 34,1 & 27,1 \\
\hline & Ogółem & 100,0 & 100,0 & 100,0 \\
\hline
\end{tabular}

Źródło: badania własne

$1-2$ braki danych

a) $\left.\chi^{2}=64,77 ; \mathrm{df}=4 ; \mathrm{p}<0,05 ; \mathrm{C}=0,42 \mathrm{~b}\right) \chi^{2}=32,64 ; \mathrm{df}=4 ; \mathrm{p}<0,05 ; \mathrm{C}=0,31$ c) $\chi^{2}=20,05 ; \mathrm{df}=4 ; \mathrm{p}<0,05 ; \mathrm{C}=0,25$

Ciekawe wyniki daje zestawienie opinii młodzieży na temat kohabitacji z planowanym wyborem stanu cywilnego w przyszłości. Zdecydowana większość respondentów planuje zawrzeć formalny związek małżeński, z wcześniejszym zamieszkaniem z partnerem/ partnerką „na próbę” (63,1\%), przy czym wybór ten cieszy się popularnością zarówno wśród uczniów religijnych, jak i obojętnych religijnie lub niewierzących (63,3\% wskazań wśród uczniów „głęboko wierzących i wierzących” wobec 63,5\% wskazań wśród uczniów „obojętnych i niewierzących”).

Obserwowany rozdźwięk pomiędzy planowanym stanem cywilnym w przyszłości a negatywną oceną konkubinatu wskazuje, iż badana młodzież fakt kohabitacji traktuje jako etap poprzedzający faktyczne, zalegalizowane małżeństwo i nie postrzega związku nieformalnego jako alternatywy dla małżeństwa. Kohabitacja w opinii badanych wydaje się raczej stanowić okres przedłużonego „chodzenia ze sobą" i etap wzmacniania wzajemnych relacji ${ }^{22}$. Ponadto, na wcześniejszym

22 Tamże, s. 417. 
etapie badań stwierdzono, iż młodzież zapytana o przyczyny odkładania decyzji matrymonialnych w czasie wskazuje obawy przed nieudanym małżeństwem $(49,9 \%$ wskazań). Powyższe czynniki w pewnym stopniu mogą wyjaśniać rozbieżność poglądów badanych uczniów, biorąc jednak pod uwagę środowisko, w jakim badana młodzież pobiera wykształcenie można by oczekiwać bardziej jednoznacznych deklaracji.

Omawiając zagadnienie kohabitacji należy zaznaczyć, iż w polskim społeczeństwie można zaobserwować niejako dwa wzory intensyfikacji zjawiska. $\mathrm{Na}$ podstawie danych GUS można powiedzieć, że zjawisko kohabitacji przybiera na sile zwłaszcza w środowisku miejskim oraz w grupie osób młodych lub rozwiedzionych $^{23}$. Zatem skłonność do generowania związków partnerskich, nieformalnych może być uwarunkowana czynnikami o charakterze psychicznym i społecznym. Osoby rozwiedzione mogą obawiać się, iż kolejne małżeństwo może być również nieudane lub osoby te, z uwagi na trudności związane z ponownym wstąpieniem w związek małżeński (kościelny) są niejako zmuszone do pozostawania w związku partnerskim, mając w perspektywie jedynie kontrakt cywilny. W przypadku osób młodych można wysnuć przypuszczenia, iż ich decyzje bardziej warunkowane są względami natury ekonomiczno - sytuacyjnej, choć nie należy wykluczać, iż chęć zażegnania obawy przed nieudanym związkiem odgrywa tu istotną rolę. W perspektywie planów ludzi młodych związek nieformalny może zatem stanowić jedynie czasowe i doraźne rozwiązanie. W Polsce możemy zatem mówić o konkubinacie czasowym (w przypadku ludzi młodych) oraz konkubinacie z konieczności (w przypadku osób rozwiedzionych). Zestawiając preferencje młodzieży lubelskiej i młodzieży ze szkół katolickich w Szczecinie w kwestii planowania przyszłego stanu cywilnego można przypuszczać, że zjawisko kohabitacji czasowej będzie się nasilać (49,8\% wobec $63,1 \%$ dla odpowiedzi „planuję w przyszłości zawrzeć formalny związek małżeński, z wcześniejszym zamieszkaniem z partnerem/ partnerką, na próbę").

Z brakiem akceptacji wśród badanej młodzieży spotyka się również zjawisko życia w pojedynkę. Życie w pojedynkę jako model gospodarstwa domowego staje się coraz bardziej popularne. Według wyliczeń Głównego Urzędu Statystycznego, w Polsce rośnie liczba jednoosobowych gospodarstw domowych. W roku 2002 liczba gospodarstw z jedną osobą obejmowała $24,8 \%$ ogółu wszystkich gospodarstw domowych, i była większa o 8,7 punktów procentowych w porównaniu do roku 1970 (16,1\%). Szacuje się, że do roku 2035 udział jednoosobowych gospodarstw w strukturze gospodarstw ogółem wzrośnie do $32,5 \%$ ²4.

${ }^{23}$ Główny Urząd Statystyczny, Ludność. Stan i struktura demograficzno-społeczna. Narodowy Spis Powszechny Ludności i Mieszkań 2011, Warszawa 2013, s. 69-70. http://stat.gov.pl/cps/rde/xbcr/ gus/LUD_ludnosc_stan_str_dem_spo_NSP2011.pdf; dostęp on-line 31.05.2014. Zob. także N. Hipsz, O roli kobiet w rodzinie, Komunikat z badań CBOS, BS/30/2013, Warszawa 2013, s. 2.

${ }^{24}$ Główny Urząd Statystyczny, Prognoza gospodarstw domowych wedtug województw na lata 2008-2035, Warszawa 2010, s. 8-12.; stat.gov.pl dostęp on-line 01.06.2014. 
Na podstawie badań własnych można stwierdzić, że niespełna połowa badanych uczniów ze Szczecina (46,9\%) ocenia życie tzw. singli zdecydowanie (12\%) lub raczej negatywnie (34,9\%). Osoby żyjące samotnie cieszą się natomiast zrozumieniem prawie u co piątego ankietowanego (19,1\% wskazań łącznie na odpowiedź „raczej pozytywnie” $i$,zdecydowanie pozytywnie”). Przy czym poparcie dla tego stylu życia jest większe wśród osób religijnie obojętnych i niewierzących. Odsetek osób oceniających zdecydowanie negatywnie życie singla jest niemal trzykrotnie większy $\mathrm{w}$ grupie osób religijnie zaangażowanych niż religijnie obojętnych i niewierzących (15\% wobec 4,7\% w kategorii odpowiedzi „zdecydowanie negatywnie”). Przekonania uczniów nie są jednoznacznie ugruntowane, ponieważ aż co trzeci respondent nie potrafił jednoznacznie ocenić takiej formy życia dorosłego (33,9\% wskazań dla kategorii „trudno powiedzieć”).

Respondentom zadano także pytanie o to, czy osoby żyjące w pojedynkę tzw. single mają ciekawsze życie niż osoby żyjące w stałych związkach. Przeprowadzone badania wykazały, że w porównaniu z życiem osób przebywających w stałych związkach, sposób życia singla jawi się jako mniej interesujący $(56,7 \%$ łącznie dla kategorii „raczej nie” i „zdecydowanie nie” wobec 16,2\% łącznie dla kategorii „,raczej tak” i „zdecydowanie tak”). Pomimo, iż zmienna „stosunek do wiary" istotnie warunkuje odpowiedzi uczniów w zakresie omawianych zagadnień, to w tym przypadku stosunek do wiary religijnej wydaje się w mniejszym stopniu współkształtować przekonania uczniów. Warto jednak zwrócić uwagę, iż osoby niereligijne częściej niż osoby wierzące miały trudności z wyrażeniem swojej opinii na ten temat (34,1\% wobec $24,3 \%$ w kategorii odpowiedzi ,trudno powiedzieć”).

Ocena życia singla dokonana przez uczniów szkół katolickich w Szczecinie jest zbieżna $\mathrm{z}$ raczej sceptycznym nastawieniem społeczeństwa polskiego. Jak wynika z badań CBOS, 61\% Polaków jest zdania, że single nie mają ciekawszego życia niż osoby żyjące $w$ stałych związkach, odmienne stanowisko prezentuje 19\% społeczeństwa. Zbliżony odsetek reprezentatywnej próby ankietowanych Polaków nie potrafił także jednoznacznie stwierdzić czy single mają ciekawsze życie niż osoby żyjące w stałych związkach (20\%). Badacze CBOS na przestrzeni ostatnich lat obserwują jednak nieznaczny wzrost fascynacji życiem singla, ponieważ w porównaniu do roku 2008 odsetek osób uznających ten styl życia za ciekawszy wzrósł o 3 punkty procentowe (z 16\% w roku 2008 do $19 \%$ W roku 2013) ${ }^{25}$.

W celu pogłębienia analizy poglądów młodzieży na temat życia w pojedynkę respondentom zadano pytanie o zalety i wady bycia singlem. Przeprowadzona analiza wykazała, że wśród najważniejszych zalet bycia osobą samotnie żyjącą ankietowani widzą brak zobowiązań (51,2\% wskazań ogółem), niezależność (48,5\% wskazań ogółem) oraz możliwość skoncentrowania się na osobistym rozwoju (37,5\%

${ }^{25}$ N. Hipsz, Społeczne oceny alternatyw życia matżeńskiego, Komunikat z badań CBOS, BS/32/2013, Warszawa 2013, s. 9. 
wskazań ogółem), przy czym na wymienione cechy częściej wskazują kobiety niż mężczyźni. W dalszej kolejności respondenci za zalety bycia singlem uznają ponoszenie odpowiedzialności wyłącznie za siebie (30,4\% wskazań ogółem) oraz poczucie wolności (29,4\% wskazań ogółem). Mężczyźni nieco częściej niż kobiety wskazują na swobodę zachowań $(29,8 \%$ wobec $20,2 \%)$ oraz możliwość zarządzania finansami w dowolny sposób (22,3\% wobec $17,7 \%)$.

Tabela 2. Zalety bycia singlem w opinii respondentów według płci (\%)/

\begin{tabular}{|c|c|c|}
\hline & Kobiety & Mężczyźni \\
\hline Niezależność & 54,5 & 36,2 \\
\hline Brak zobowiązań & 52,5 & 48,9 \\
\hline Skoncentrowanie się na osobistym rozwoju & 40,4 & 30,9 \\
\hline Odpowiedzialność tylko za siebie & 30,3 & 30,9 \\
\hline Poczucie wolności & 29,3 & 29,8 \\
\hline Swoboda zachowań & 20,2 & 29,8 \\
\hline Więcej wolnego czasu & 18,7 & 20,2 \\
\hline Zarządzanie finansami w dowolny sposób & 17,7 & 22,3 \\
\hline Bycie singlem nie ma żadnych zalet & 6,6 & 7,4 \\
\hline Trudno powiedzieć & 2,5 & 8,5 \\
\hline Inne & 1,0 & 0,0 \\
\hline
\end{tabular}

Źródło: badania własne

* odsetki nie sumują się do stu, ponieważ ankietowani mogli zaznaczyć większą ilość odpowiedzi

Powyższe wyniki wskazują, iż zdaniem badanych uczniów największymi beneficjentami życia singla są sami zainteresowani, dla których największą korzyścią wypływającą z przyjęcia takiego stylu życia jest orientacja na niezależność i samorealizację.

W celu przeprowadzenia całościowej analizy omawianego zagadnienia poproszono młodzież również o wyrażenie opinii na temat minusów życia w pojedynkę. Okazuje się ponowczesny styl życia singla ma swoją społeczną cenę. Uzyskane rezultaty pozwalają stwierdzić, że do mankamentów samotnego życia młodzi najczęściej zaliczają poczucie osamotnienia (78,5\% wskazań ogółem), brak wsparcia (63,1\% wskazań ogółem) oraz brak stałych i intymnych relacji z partnerem $(44,4 \%$ wskazań ogółem). W dalszej kolejności ankietowani wskazują na brak poczucia sensu życia w dłuższej perspektywie (39,9\% wskazań ogółem), brak opieki na starość (21,2\% wskazań ogółem) i konieczność samodzielnego radzenia sobie z codziennymi obowiązkami (20,8\% wskazań ogółem). Za stosunkowo marginalne wady bycia singlem respondenci uznają fakt zwiększonych kosztów utrzymania, jakie trzeba ponosić w przypadku jednoosobowego gospodarstwa domowego $(3,1 \%$ wskazań ogółem) oraz konieczność zmagania się z negatywnym wizerunkiem singla w oczach społeczeństwa (2,7\% wskazań ogółem). 
Tabela 3. Wady bycia singlem w opinii respondentów według stosunku do wiary (\%).

\begin{tabular}{|c|c|c|}
\hline & $\begin{array}{c}\text { Obojętni } \\
\text { i niewierzący }\end{array}$ & $\begin{array}{c}\text { Głęboko wierzący } \\
\text { i wierzący }\end{array}$ \\
\hline Poczucie osamotnienia & 76,5 & 79,2 \\
\hline Brak wsparcia & 55,3 & 66,2 \\
\hline Brak intymnych relacji ze stałym partnerem & 51,8 & 41,1 \\
\hline Brak poczucia sensu życia w dłuższej perspektywie & 35,3 & 42,0 \\
\hline Brak opieki na starość & 20,0 & 21,7 \\
\hline Samodzielna troska o obowiązki codzienne & 20,0 & 21,3 \\
\hline Większe koszty utrzymania & 7,1 & 1,4 \\
\hline Negatywne postrzeganie przez społeczeństwo & 2,4 & 2,9 \\
\hline Bycie singlem nie ma żadnych wad & 3,5 & 1,4 \\
\hline Inne & 0,0 & 0,5 \\
\hline Trudno powiedzieć & 3,5 & 2,9 \\
\hline
\end{tabular}

Źródto: badania własne

* odsetki nie sumują się do stu, ponieważ ankietowani mogli zaznaczyć większą ilość odpowiedzi

W przypadku analizy dwuzmiennowej i rozróżnienia na osoby bardziej i mniej zaangażowane religijnie zauważyć można, iż osoby bardziej religijne częściej zwracają uwagę na aspekty egzystencjalne (brak wsparcia - 66,2\% wobec 55,3\%, brak poczucia sensu życia - $42 \%$ wobec $35,3 \%$ ), natomiast zdaniem osób obojętnych religijnie i niewierzących większym mankamentem jest brak regularnych kontaktów seksualnych ze stałym partnerem (51,8\% wobec $41,1 \%)$.

Ostatnim omawianym zagadnieniem w tej części niniejszego opracowania są poglądy młodzieży na temat praw osób homoseksualnych. Tolerancja wobec homoseksualizmu staje się najbardziej charakterystycznym symbolem ponowoczesnych przemian i transformacji, polegających na wytyczeniu normom społeczno-kulturowym nowych granic ${ }^{26}$. Trwałą oznaką legitymizacji przemian i nowego porządku staje się poszerzenie zakresu uprawnień par jednopłciowych do zawierania małżeństw i adopcji, aż do całkowitego uznania i zrównania praw par hetero- i homoseksualnych. Dyskurs publiczny, wokół którego ogniskują się kwestie praw osób homoseksualnych najczęściej przyjmuje zabarwienie polityczno-światopoglądowe, czy religijno-moralne, polaryzując postawy zwolenników, jak i oponentów poszczególnych opcji światopoglądowych ${ }^{27}$.

Jak wynika z międzynarodowych badań CBOS przeprowadzonych w roku 2005 w Polsce, Czechach, Słowacji i na Węgrzech najbardziej oswojeni ze zjawiskiem homoseksualizmu są Czesi - prawie 2/5 naszych południowo-zachodnich sąsiadów zadeklarowało osobistą znajomość osoby homoseksualnej (43\%). Najmniejszy kontakt ze zjawiskiem homoseksualizmu w tym czasie mieli Węgrzy, których je-

${ }^{26}$ T. Szlendak, Socjologia rodziny. Ewolucja, historia, zróżnicowanie, Warszawa 2012, s. 486.

27 D. Majka-Rostek, Zwiazki homoseksualne. Studium socjologiczne, Warszawa 2008, s. 62-69. 
dynie $8 \%$ mogło pochwalić się osobistą znajomością geja lub lesbijki. Polacy pod tym względem wypadli podobnie, bowiem co siódmy dorosły Polak deklarował znajomość osoby homoseksualnej $(14 \%)^{28}$.

Ogólnie, w obszarze państw Europy Środkowo-Wschodniej w kwestii praw par homoseksualnych do zawierania związków małżeńskich i adopcji obserwowano w tym czasie poglądy raczej sceptyczne. W badanych krajach stanowisko najbardziej liberalne prezentowali Czesi, których większość wyrażała pogląd, iż pary homoseksualne powinny zawierać związki niebędące małżeństwem, ale z prawem np. do dziedziczenia po partnerze lub do wspólnego rozliczania podatków $(62 \%)$. Polacy podobny pomysł przyjmowali z mniejszym entuzjazmem (42\%). W kwestii adoptowania dzieci najbardziej liberalne poglądy ujawniali Węgrzy, których 1/4 aprobowała ten pomysł $(25 \%)^{29}$.

Poglądy Polaków na temat praw osób homoseksualnych wydają się być utrwalone, choć na przestrzeni ostatnich lat postawy wobec gejów i lesbijek w Polsce uległy niewielkim zmianom. W roku 2010 odsetek osób osobiście znających osobę homoseksualną wzrósł z 16\% w roku 2005 do $24 \%$ w roku 2010, co może świadczyć o stopniowym ujawnianiu się tej grupy osób w przestrzeni społecznej. W porównaniu do roku 2005 wzrosła także aprobata dla urządzania publicznych manifestacji (z 20\% do 30\% w roku 2010) i publicznego okazywania sposobu życia par jednopłciowych (z 16\% do 29\% w roku 2010). Poglądy Polaków na zakres uprawnień par tej samej płci wydają się być ugruntowane i można je określić jako zdecydowanie przeciwne idei poszerzaniu praw wobec osób homoseksualnych, z wyjątkiem rosnącej akceptacji (od roku 2003) dla zawierania związków partnerskich (34\% dla kategorii „tak” w roku 2003 do 45\% w roku 2010). Rosnąca tolerancja Polaków wobec zjawiska homoseksualizmu wyraża się wzrostem odsetka osób uważających co prawda pociąg seksualny do osób tej samej płci za odstępstwo od normy, ale takie, które należy tolerować (47\% w roku 2001 do 63\% w roku 2010). Jednocześnie zmniejsza się odsetek osób, które twierdzą, że homoseksualizm nie jest normalny i nie wolno tego zjawiska tolerować (41\% w roku 2001 do $23 \% \mathrm{w}$ roku 2010$)^{30}$.

Wyniki badań własnych wykazały relatywnie równomierny rozkład opinii na temat praw osób homoseksualnych. Ankietowanych poproszono o wyrażenie opinii za pomocą skali pomiarowej, obejmującej zakres uprawnień z jednej strony zrównujących pary jednopłciowe z małżeństwami heteroseksualnymi, a z drugiej odbierającej gejom i lesbijkom możliwość jakiejkolwiek formalizacji swojego związku. Na podstawie przeprowadzonych analiz można stwierdzić, że niemal co trzeci respondent optuje za całkowitym uniemożliwieniem parom jednopłciowym jakiejkolwiek możliwości formalizacji swojego związku (34,6\%). Nieco łagodniejsze

${ }^{28} \mathrm{M}$. Wenzel, Osobista znajomość i akceptacja praw gejów i lesbijek w krajach Europy Środkowej, Komunikat z badań CBOS, BS/178/2005, Warszawa 2005, s. 2-3.

${ }^{29}$ Tamże.

${ }^{30}$ M. Feliksiak, Postawy wobec gejów i lesbijek, Komunikat z badań CBOS, BS/95/2010, Warszawa 2010, s. 1-3, 12-14. 
podejście, zakładające ułatwienie gejom i lesbijkom formalizacji związku prezentuje prawie $1 / 4$ badanych uczniów (23,6\%), a niemalże $1 / 5$ jest skłonna udzielić osobom homoseksualnym prawa do małżeństwa na zasadzie całkowitego zrównania z małżeństwami heteroseksualnymi (19,5\%), bądź z wykluczeniem części uprawnień, np. prawa do adopcji $(18,5 \%)$.

Tabela 4. Poglądy na temat praw par homoseksualnych według płci, stosunku do wiary i wielkości miejscowości pochodzenia (\%).

\begin{tabular}{|c|c|c|c|c|c|c|c|c|}
\hline & \multicolumn{2}{|c|}{ Płeća) } & \multicolumn{2}{|c|}{$\begin{array}{c}\text { Stosunek do } \\
\text { wiary }^{\text {b) }}\end{array}$} & \multicolumn{3}{|c|}{$\begin{array}{l}\text { Wielkość miejscowo- } \\
\text { ści pochodzenia }{ }^{\text {c) }}\end{array}$} & \multirow[b]{2}{*}{ 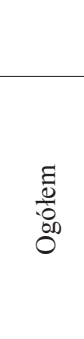 } \\
\hline & 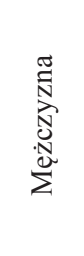 & $\begin{array}{l}\frac{\pi}{0} \\
\frac{0}{0} \\
0 \\
1\end{array}$ & 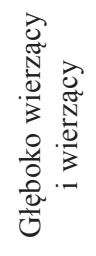 & 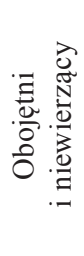 & $\stackrel{n}{3}$ & 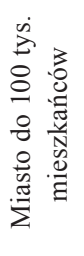 & 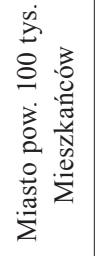 & \\
\hline & $\mathrm{N}=94$ & $\mathrm{~N}=198$ & $\mathrm{~N}=207$ & $\mathrm{~N}=85$ & $\mathrm{~N}=50$ & $\mathrm{~N}=46$ & $\mathrm{~N}=196$ & $\mathrm{~N}=292$ \\
\hline $\begin{array}{l}\text { Uważam, że pary homoseksualne po- } \\
\text { winny mieć prawo do małżeństwa ze } \\
\text { wszystkimi prawami jak małżeństwa } \\
\text { heteroseksualne }\end{array}$ & 3,2 & 27,3 & 12,1 & 37,6 & 16,0 & 34,8 & 16,8 & 19,5 \\
\hline $\begin{array}{l}\text { Uważam, że pary homoseksualne po- } \\
\text { winny mieć prawo do małż., ale nie } \\
\text { powinny mieć takich samych praw } \\
\text { jak małż. heteroseks. (np. adopcja) }\end{array}$ & 11,7 & 21,2 & 16,4 & 23,5 & 26,0 & 30,4 & 13,8 & 18,5 \\
\hline $\begin{array}{l}\text { Uważam, że pary homoseksualne nie } \\
\text { powinny mieć prawa do małżeństwa, } \\
\text { ale powinny mieć możliwość jakiejś } \\
\text { formalizacji związku }\end{array}$ & 17,0 & 26,8 & 25,6 & 18,8 & 22,0 & 10,9 & 27,0 & 23,6 \\
\hline $\begin{array}{l}\text { Uważam, że pary homoseksualne } \\
\text { nie powinny mieć prawa w jakikol- } \\
\text { wiek sposób formalizować swojego } \\
\text { związku }\end{array}$ & 63,8 & 21,2 & 43,0 & 14,1 & 32,0 & 17,4 & 39,3 & 34,6 \\
\hline Nie mam zdania & 4,3 & 3,5 & 2,9 & 5,9 & 4,0 & 6,5 & 3,1 & 3,8 \\
\hline
\end{tabular}

Źródło: badania własne

1 - brak danych

a) $\chi^{2}=57,90 ; \mathrm{df}=4 ; \mathrm{p}<0,05 ; \mathrm{C}=0,40$ b) $\left.\chi^{2}=38,95 ; \mathrm{df}=4 ; \mathrm{p}<0,05 ; \mathrm{C}=0,34 \mathrm{c}\right) \chi^{2}=24,62 ; \mathrm{df}=8 ; \mathrm{p}<0,05 ; \mathrm{C}=0,27$

Analiza statystyczna wykazała ponadto, iż poglądy konserwatywne i bardziej rygorystyczne wobec osób homoseksualnych istotnie częściej ujawniają mężczyźni, osoby wierzące, pochodzące ze wsi lub ze Szczecina. Osoby obojętne religijnie lub deklarujące się jako niewierzące oraz kobiety niemal trzykrotnie rzadziej niż religijnie zaangażowane i mężczyźni prezentują pogląd, że pary jednopłciowe nie powinny mieć prawa $\mathrm{w}$ jakikolwiek sposób formalizować swojego związku $(21,2 \%$ 
kobiet wobec $63,8 \%$ mężczyzn; $14,1 \%$ obojętnych i niewierzących wobec $43 \%$ głęboko wierzących i wierzących dla kategorii „pary homoseksualne nie powinny mieć prawa w jakikolwiek sposób formalizować swojego związku"). Ponadto warto zauważyć, że nastawienie liberalne, zakładające całkowite zrównanie par heteroi homoseksualnych niemal dwukrotnie częściej deklarują uczniowie pochodzący z mniejszych miejscowości, niż mieszkańcy wsi i Szczecina $(34,8 \%$ wobec $16 \%$ i 16,8\% dla kategorii ,pary homoseksualne powinny mieć prawo do małżeństwa ze wszystkimi prawami jak małżeństwa heteroseksualne").

Poglądy młodzieży na temat alternatywnych form życia małżeńskiego kształtowane są głównie przez środki masowego przekazu (Internet, telewizja, czasopisma) ${ }^{31}$. Oznacza to, że młodzież swoją wiedzę na temat roszczeń par jednopłciowych odnośnie prawa do zawierania związków czerpie z komunikatów i relacji medialnych, natomiast interpretacje i poglądy buduje na bazie własnych przekonań, atmosfery panującej w domu rodzinnym oraz odczuć religijnych. Płaszczyzny opiniotwórcze przenikają się generując stosunkowo szeroki obszar umiarkowanej tolerancji młodzieży wobec zjawiska homoseksualizmu, równocześnie sprzeciwiając się najbardziej skrajnym przejawom obecności par jednopłciowych w przestrzeni publicznej. Tendencja ta jest wyraźne widoczna na przykładzie badań młodzieży gimnazjalnej. Jak zauważa Józef Baniak, „choć tak wielki odsetek badanych gimnazjalistów $(67,3 \%)$ świadomie toleruje tendencje i zachowania homoseksualne kobiet i mężczyzn, sprzeciwiają się oni zarówno publicznemu manifestowaniu tych odmienności seksualnych, jak i umożliwianiu homoseksualistom obojga płci prawa do adopcji dzieci i zawierania przez nich formalnych związków małżeńskich. To prawo przysługuje, zdaniem $86,8 \%$ badanych dziewcząt i $76,3 \%$ badanych chłopców, wyłącznie legalnym małżeństwom lub trwałym heteroseksualnym związkom konkubenckim, gdyż «tylko w takich małżeństwach i rodzinach dzieci mogą wyrosnąć i być wychowane na mądrych i uczciwych ludzi, a również w tych środowiskach rozwinie się właściwa seksualność dziecka, dziewczynki i chłopca» - stwierdziła W wypowiedzi uczennica trzeciej klasy gimnazjum wiejskiego"32.

Interpretacja ta znajduje potwierdzenie w analizie badań własnych. Gdy z analizy wyłączymy osoby jednoznacznie sprzeciwiające się parom homoseksualnym $(34,6 \%)$ oraz osoby, które nie wyraziły jednoznacznie swojej opinii na temat $(3,8 \%$ dla kategorii „trudno powiedzieć”), otrzymamy całkiem pokaźne grono osób (61,6\% łącznie dla pozostałych kategorii), które w mniejszym bądź większym stopniu optuje za jakąś formą legitymizacji obecności par jednopłciowych w przestrzeni publicznej, od całkowitego zrównania praw z małżeństwami heteroseksualnymi do umożliwienia osobom homoseksualnym formalizacji swojego związku w jakiś sposób.

${ }^{31}$ J. Baniak, Matżeństwo i rodzina w świadomości młodzieży gimnazjalnej na tle kryzysu jej tożsamości osobowej. Studium socjologiczne, Kraków 2010, s. 110.

32 Tamże, s. 105. 
Powyższą interpretację wydają się potwierdzać badania Janusza Mariańskiego wśród młodzieży szkół średnich. Młodzież szkolna z różnych miast polskich oceniała homoseksualizm według 7-punktowej skali: od -3, gdy tego rodzaju zachowanie jest całkowicie nieusprawiedliwione, do +3 , gdy jest całkowicie usprawiedliwione. Cyfra 0 na skali oznaczała obojętny stosunek wobec zjawiska homoseksualizmu ${ }^{33}$. Analiza rezultatów przeprowadzonych przez Janusza Mariańskiego badań ujawniła, że najczęściej wybieranymi wartościami na skali ilościowej były „-3” i „0” (np. kolejno 35,8\% i 30,7\% w Lublinie). Zbliżone rozkłady obserwowano wśród młodzieży szkół średnich z innych miast objętych badaniami ${ }^{34}$. Obserwacje te wskazują, iż poglądy młodzieży na temat zjawiska homoseksualizmu sytuują się pomiędzy całkowitą dezaprobatą a obojętnością. Wypadkową takiego sposobu postrzegania rzeczywistości społecznej jest ustępliwa tolerancja wobec osób homoseksualnych, zakładająca udzielenie pewnych uprawnień, ale równocześnie wykluczająca najszerszą i najbardziej liberalną interpretację, która zrównywałaby pary jednopłciowe z małżeństwami heteroseksualnymi.

\section{PODSUMOWANIE}

Podsumowując omawiane zagadnienia można stwierdzić, że badana młodzież raczej negatywnie ocenia wybrane, alternatywne formy życia małżeńsko-rodzinnego: kohabitację i życie w pojedynkę. W kwestii uprawnień par jednopłciowych badana młodzież ujawnia szeroki zakres opinii, wśród których najczęściej prezentowanym stanowiskiem jest opór wobec umożliwienia gejom i lesbijkom zawierania jakichkolwiek związków formalnych. Jednak pozostali ankietowani, którzy w różnym stopniu są skłonni poszerzyć zakres uprawnień par homoseksualnych do zawierania związków formalnych, razem wzięci tworzą najliczniejszą kategorię.

Obserwowany stan rzeczy wskazuje na ciągłą aktualność tezy postawionej przez Janusza Mariańskiego, który zwrócił uwagę na przemiany świadomości prorodzinnej młodego pokolenia Polaków, sytuującej się pomiędzy społecznymi procesami sekularyzacji i ewangelizacji. „Silne są tendencje sekularyzacyjne i związane z indywidualizacją moralną, ale także przeciwstawne im tendencje reewangelizacyjne. Wiele faktów wskazuje na to, że w przemianach wartości prorodzinnych mieszają się pozytywne i negatywne aspekty, a niekiedy zaznaczają się nawet sprzeczne tendencje. Efektem tych oddziaływań jest fakt, że niejednokrotnie w świadomości zbiorowej młodych Polaków współistnieją „stare” i „nowe” wartości. Nie grozi

33 J. Mariański, Między sekularyzacją i ewangelizacją. Wartości prorodzinne w świadomości młodzieży szkót średnich, Lublin 2003, s. 282.

34 Tamże, s. 283. 
nam - przynajmniej w najbliższej przyszłości - jakaś katastrofa w świecie wartości. Można raczej mówić o swoistej ambiwalencji przemian wartości prorodzinnych, o szansach i ryzyku, o stratach i zyskach, o poszerzającej się sferze przyzwolenia społecznego na postawy i zachowania dezaprobowane w modelu moralności głoszonej w Polsce przez Kościół katolicki’35.

Wyniki przeprowadzonych badań mogą wskazywać, iż młodzież podatna na oddziaływanie laickiego systemu norm i wartości dostrzega jednocześnie rolę czynników religijnych i w jakimś stopniu chce również przyjąć chrześcijański model małżeństwa i rodziny. Efektem oddziaływania dwóch modeli aksjonormatywnych, na bazie których młodzież buduje swoje przekonania i światopogląd jest pewien ideologiczny i myślowy kompromis postaw w zakresie życia małżeńsko - rodzinnego. Nie należy zatem spodziewać się, że młode pokolenie w najbliższym czasie stanie się nośnikiem rewolucyjnych rozwiązań w zakresie życia małżeńsko-rodzinnego, choć konieczne jest zwrócenie uwagi na fakt, że zdecydowana większość z nich planuje kohabitację czasową i zamierza zamieszkać z partnerem/ partnerką przed ślubem. Nie przeszkadza to jednak większości młodzieży składać deklaracji związanych z wysokimi oczekiwaniami moralnymi wobec ewentualnego współmałżonka - większość uczniów przyznaje, że chciałaby być dla swojego przyszłego współmałżonka pierwszym partnerem seksualnym (68,1\%). Znaczny odsetek uczniów aprobujących nowe formy życia małżeńskiego i rodzinnego w grupie osób obojętnych religijnie i niewierzących pozwala wysnuć wniosek, iż akceptacja i tolerancja dla nowych zjawisk w obszarze życia rodzinnego może w jakimś stopniu zależeć od siły bądź kierunku procesu sekularyzacji społeczeństwa polskiego.

\section{BIBLIOGRAFIA}

Baniak J., Matżeństwo i rodzina w świadomości młodzieży gimnazjalnej na tle kryzysu jej tożsamości osobowej, Kraków 2010.

Biernat T., Sobierajski P., Młodzież wobec matzeństwa i rodziny. Raport z badań, Toruń 2007.

Boguszewski R., Kontrowersje wokót różnych zjawisk dotyczących życia małżeńskiego i rodzinnego, Komunikat z badań CBOS, BS/54/2008, Warszawa 2008.

Feliksiak M., Postawy wobec gejów i lesbijek, Komunikat z badań CBOS, BS/95/2010, Warszawa 2010.

Feliksiak M., Stosunek do praw gejów i lesbijek oraz związków partnerskich, Komunikat z badań CBOS, BS/24/2013, Warszawa 2013.

Gębuś D., Rodzina tak, ale jaka?, Warszawa 2006.

Gizicka D., Kohabitacja - droga do matżeństwa czy jego alternatywa?, w: Miłość, wierność i uczciwość na rozstajach współczesności. Ksztatty rodziny wspótczesnej, red. W. Muszyński, E. Sikora, Toruń 2008.

Gizicka D., Kohabitacja jako alternatywna forma życia matżeńskiego, „Roczniki Nauk Społecznych" 2008, t. 36, z. 1., s.

Główny Urząd Statystyczny, Gospodarstwa domowe w 2011 roku-wyniki spisu ludności i mieszkań 2011 - materiat na konferencje prasowa w dniu 29.01.2013 r., Warszawa 2013.

\footnotetext{
${ }^{35}$ Tamże, s. 485.
} 
Główny Urząd Statystyczny, Ludność. Stan i struktura demograficzno-społeczna. Narodowy Spis Powszechny Ludności i Mieszkań 2011, Warszawa 2013.

Główny Urząd Statystyczny, Prognoza gospodarstw domowych wedtug województw na lata 2008-2035, Warszawa 2010.

Hipsz N., O roli kobiet $w$ rodzinie, Komunikat z badań CBOS, BS/30/2013, Warszawa 2013.

Hipsz N., Społeczne oceny alternatyw życia matżeńskiego, Komunikat z badań CBOS, BS/32/2013, Warszawa 2013.

Lew-Starowicz Z., Lew-Starowicz M., Homoseksualizm, Warszawa 1999.

Majka-Rostek D., Zwiazki homoseksualne. Studium socjologiczne, Warszawa 2008.

Mariański J., Między sekularyzacją i ewangelizacją. Wartości prorodzinne w świadomości mtodzieży szkót średnich, Lublin 2003.

Ruszkiewicz D., Życie w pojedynke - ucieczka od rodziny czy znak naszych czasów?, Łódź 2008.

Sikorska M., Nowa matka, nowy ojciec, nowe dziecko. O nowym uktadzie sit w polskich rodzinach, Warszawa 2009.

Szlendak T., Socjologia rodziny. Ewolucja, historia, zróżnicowanie, Warszawa 2012.

Szukalski P., Kohabitacja w Polsce, w: Rodzina w zmieniajacym się społeczeństwie polskim, red. W. Warzywoda-Kruszyńska, P. Szukalski, Łódź 2004.

Szyszka M., Współczesna rodzina - polskie dylematy, w: Społeczeństwo-Przestrzeń-Rodzina. Ksiega jubileuszowa dedykowana Profesorowi Piotrowi Kryczce, red. M. Szyszka, Lublin 2009.

Wenzel M., Osobista znajomość i akceptacja praw gejów i lesbijek w krajach Europy Środkowej, Komunikat z badań CBOS, BS/178/2005, Warszawa 2005.

Żurek A., Czas wolny singli - pomiędzy rodzina a przyjaciótmi, w: Miłość, wierność i uczciwość na rozstajach współczesności. Kształty rodziny wspótczesnej, red. W. Muszyński, E. Sikora, Toruń 2008.

Żurek A., Single. Żyjąc w pojedynkę, Poznań 2008.

\section{Streszczenie}

Przemiany w sferze życia małżeńsko-rodzinnego wiążą się ze wzrostem akceptacji wobec nowych form życia w małżeństwie i rodzinie. Zakres obserwowanych przemian pozwala przypuszczać, że w społeczeństwie polskim młode pokolenie stanie się nośnikiem rewolucyjnych rozwiązań w życiu małżeńsko-rodzinnym. Głównym celem artykułu jest udzielenie odpowiedzi na pytane, jaki jest społeczny odbiór nowych form życia małżeńsko-rodzinnego w świadomości młodzieży licealnej. W artykule prezentowane są rezultaty badań socjologicznych dotyczące oceny i stosunku młodzieży katolickich szkół średnich w Szczecinie wobec zjawiska kohabitacji, życia w pojedynkę i możliwości zawierania związków przez pary jednopłciowe.

Słowa kluczowe: małżeństwo, rodzina, młodzież, kohabitacja, pary homoseksualne, życie w pojedynkę 


\title{
ATTITUDES OF YOUTH TOWARDS ALTERNATIVE FORMS \\ OF MARRIAGE AND FAMILY LIFE. BASED ON SOCIOLOGICAL RESEARCH \\ IN CATHOLIC HIGH SCHOOLS IN SZCZECIN
}

\begin{abstract}
Sum mary
Changes in the area of marriage and family life bring about rising acceptance towards new forms and alternatives of family. The scope of perceived changes suggests that in Polish society the younger generations will become carriers of revolutionary solutions and changes of family life.

This report aims to answer the question: what is the social reception of the new forms of marriage and family life among high school students. The report presents results of sociological research regarding evaluation and perception of the Catholic youth in Szczecin towards cohabitation, single life and acceptance for same-sex marriages.
\end{abstract}

Keywords: marriage, family, youth, cohabitation, same-sex marriage, single life 